\title{
Mapping Of Leptospirosis Environmental Risk Factors and Determining the Level of Leptospirosis Vulnerable Zone In Demak District Using Remote Sensing Image
}

\author{
Siti Rahayu ${ }^{1}$, Mateus Sakundarno Adi $^{2}$, and Lintang Dian Saraswati ${ }^{{ }^{*}}$ \\ ${ }^{1}$ Department Epidemiology and Tropical Diseases, Public Health Faculty, Diponegoro University, Semarang, Indonesia, 50275 \\ ${ }^{2}$ Master Program of Epidemiology, School of Postgraduate Studies Diponegoro University, Semarang, Indonesia
}

\begin{abstract}
Leptospirosis, a zoonotic disease, transmitted to human trough contact with contaminated animal urine and contaminated environment. Demak District is an endemic area where cases increased in the past 2 years. The aim of the study was to map environmental risk factor of Leptospirosis and to determine Leptospirosis vulnerable zone using cross-sectional study design. There were 42 cases mapped by GPS and overlaid using remote sensing (Quickbird image) by using ArcView program then interpreted by Spatial Feature and Spatial Analyses. Leptospirosis cases were spread out and grouped in Demak Sub District area. More cases were males (61.9\%), 21-50 years old age group (59.3\%) and farmers (40.4\%). Spatial analyses showed that all the leptospirosis cases took place in the area with low plain $<47 \mathrm{msl}$, rainfall $\geq 220 \mathrm{~mm} /$ month $(64.7 \%)$, clay soil $(100 \%)$, buffer river $<50 \mathrm{~m}(71.4 \%)$, presence of rat (100\%), wastewater disposal (100\%), waste disposal facilities (97.7\%), flood's profile (28.6\%), tidal inundation's profile $(7.1 \%)$, vegetation (59.5\%). Leptospirosis high-risk zone was in $37,801.8$ ha $(41.32 \%)$, moderate risk zone was 43,570.23 ha (48.55\%), and low-risk zone was 9,090.96 ha (10.13\%). Densely populated housing, bad environment condition, and the presence of rat and puddles that were contaminated by rat's urine were risk factors of Leptospirosis cases in Demak District.
\end{abstract}

\section{Introduction}

Leptospirosis is a worldwide public health problem, especially in tropical and subtropical countries with high rainfall, and is also a major problem in temperate regions [1]. Leptospirosis, caused by pathogenic spirochetes belonging to the genus Leptospira, is a zoonosis that has important impacts on human and animal health worldwide [2]. Transmission to mammals occurs via direct contact with leptospirainfected urine or tissues or indirectly through contact with contaminated soil or water. Although infection may take place through unbroken skin after prolonged immersion, Leptospira sp usually gain entry to the host via abrasions or cuts in the skin or through exposed mucosae (eyes, nose, etc.). Incidence is seasonal, peaking in summer and fall in temperate climates and during the rainy season in tropical areas, mirroring the ability of the bacteria to survive in the external environment. Soil [3], [4], mud [5], and surface waters contaminated with urine from chronically-infected reservoir hosts remain important sources of human leptospirosis transmission worldwide [6]-[8].

The incidence of Leptospirosis in subtropical countries is in the range of $0.1-1$ incidence per 100,000 population per year, whereas in tropical countries it ranges from 10-100 incidence per 100,000 population per year [1]. Indonesia as a tropical country becomes one of them. The International Leptospirosis Society states that Indonesia is one of the tropical countries with relatively high leptospirosis death cases, ranging from $2.5 \%-16.45 \%$ or an average of $7.1 \%$ and is ranked third in the world. Leptospirosis cases in Indonesia in 2012 among 239 patients, 29 people died (CFR 12.13\%), in 2013 there are an increasing number of Leptospirosis cases with 640 patients, 60 people died (CFR 9.38\%). Leptospirosis cases in 2014 slightly decreased by 519 patients, 61 people died (CFR $11.75 \%$ ) [1], [8].

Demak District is one of the endemic areas of Leptospirosis in Central Java Province with a mortality rate of Leptospirosis exceeding the national average (7.1\%). According to Health Office of Demak District in 2015, there are 13 patients of Leptospirosis cases and 2 people died in 2012 (CFR 15.3\%). In 2013, there are 17 patients of Leptospirosis cases and 2 people died (CFR 11.7\%), in 2014 it's increased by 30 patients and 5 people died (CFR 16.6\%), and in 2015 there are 12 patients and 1 person died $(8.3 \%)$.

Corresponding author: lintang.saraswati@live.undip.ac.id 
The occurrence of infectious diseases is influenced by three factors: Agent, Host, and Environment [9]-[11]. The agent of Leptospirosis disease is Leptospira bacteria [12], [13]. The main hosts are rats and pets such as dogs, cats, and cows [2], [12], [13]. The accidental host is human [14], [15]. In the tropical climatic zone, where environmental conditions are most favorable for survival of Leptospira and the highest morbidity is noted, extreme weather events such as cyclones and floods occurring in recent years with increasing frequency and greater intensity, may potentially result in an upsurge in the disease incidence, as well as the magnitude of leptospirosis outbreaks [16]-[18].

The high prevalence rate of Leptospirosis in tropical and subtropical climates can be attributed to adverse environmental conditions that allow the environment to be a suitable place to live and develop of Leptospira bacteria [5], [19]. Our previous study showed mapping and analysis of environmental conditions are needed to determine the picture of environmental factors existed and have a risk for the incidence of Leptospirosis [20].

The mapping can be done by utilizing Geographic Information System (GIS). Geographic Information System is a special case where database consist of observations on spatially distributed features, activities, or events, which are definable in space as point, lines, or areas [21], [22]. Remotely sensed imagery is an effective data source for urban environment analysis that is inherently suited to provide information on urban land cover characteristics and their changes over time at various spatial and temporal scales without being in contact with it [23]-[25].

Both technologies are very useful in the management of spatial information of earth surface condition [26], [27]. Recently, the use of GIS and spatial representation of various health issues make professionals arrive at conclusions in a faster and better way in the field of both public health and decisionmaking. The use of these systems has a wide impact on the public health and lots of studies are based on them $[17,18]$.

\section{Methods}

An observational study with the cross-sectional design was used for mapping environmental risk factors and determining the level of Leptospirosis vulnerable zone using remote sensing image in Demak District. Primary data were an environmental risk factor and coordinate location point using GPS. Secondary data were a number of leptospirosis cases and digital SHP map of Demak District in 1:25,000 scale (Administration Border, Land Use, River, Road, Contour, Altitude, Soil Texture, Flood Area, and Rainfall). There were 42 leptospirosis cases.

The data obtained was mapped with the GPS Mobile Topographer with the ArcView program built with Quickbird image. After visual interpretation and screen digitalization to visual identification of environmental risk factors. Spatial modeling analysis of environmental factors and distribution of Leptospirosis cases with overlay process to determine the level of Leptospirosis vulnerable zone.

\section{Results and discussions}

The result of this study indicates that more than half of respondents are male by $61.9 \%$ or as many as 26 cases. The result is different from the condition of the population in Demak District, where the female population is larger than male. Both men and women are equally at risk to be infected by leptospirosis, but men are at greater risk for Leptospirosis infection due to several things, such as activity and occupation.

Table.1 Characteristic of Respondents by Sex, Education Level, and Occupation $(\mathrm{n}=42)$

\begin{tabular}{|l|r|r|}
\hline $\begin{array}{c}\text { Characteristics of } \\
\text { Respondents }\end{array}$ & Frequency & Percentage (\%) \\
\hline 1. Sex & 26 & \\
a. Male & 16 & 61.9 \\
b. Female & & 38.1 \\
2. Occupation & 4 & \\
a. Entrepreneur & 3 & 9.5 \\
b. Labor & 1 & 7.1 \\
c. Civil Servant & 7 & 2.3 \\
d. Housewife & 17 & 16.6 \\
e. Farmer & 2 & 40.4 \\
f. Scavenger & 4 & 4.7 \\
g. Merchants & 1 & 9.5 \\
h. Pedicab Driver & 2 & 2.3 \\
i. Fisherman & 1 & 4.7 \\
j. Student & & 2.3 \\
\hline
\end{tabular}

Table.2 Frequency Distribution of Leptospirosis Cases in Leptospirosis Case Area in Demak District in 2014-2015

\begin{tabular}{|c|c|c|}
\hline Variable & Frequency & $\begin{array}{l}\text { Percetg. } \\
\text { (\%) }\end{array}$ \\
\hline $\begin{array}{r}\text { 1.Topography } \\
\text { a. }<47 \text { masl } \\
\text { b. } \geq 47 \text { masl }\end{array}$ & $\begin{array}{c}42 \\
0\end{array}$ & $\begin{array}{c}100 \\
0\end{array}$ \\
\hline $\begin{array}{l}\text { 2.The distance between River } \\
\text { and House } \\
\text { a. }<50 \mathrm{~m}=\text { at risk } \\
\text { b. } 50-300 \mathrm{~m}=\text { moderate } \\
\text { c. }>300 \mathrm{~m}=\text { good }\end{array}$ & $\begin{array}{c}30 \\
12 \\
0\end{array}$ & $\begin{array}{c}71.4 \\
28.6 \\
0\end{array}$ \\
\hline $\begin{array}{l}\text { 3.Rainfall } \\
\text { a. } \geq 220 \mathrm{~mm} / \text { month } \\
\text { b. }<220 \mathrm{~mm} / \text { month }\end{array}$ & $\begin{array}{l}27 \\
15\end{array}$ & $\begin{array}{l}64.3 \\
36.7\end{array}$ \\
\hline $\begin{array}{l}\text { 4. The presence of Rats } \\
\text { a. Present } \\
\text { b. None }\end{array}$ & $\begin{array}{c}42 \\
0\end{array}$ & $\begin{array}{c}100 \\
0\end{array}$ \\
\hline $\begin{array}{l}\text { 5.Wastewater Disposal Facility } \\
\text { a. Good } \\
\text { b. PooR }\end{array}$ & $\begin{array}{c}42 \\
0\end{array}$ & $\begin{array}{c}100 \\
0\end{array}$ \\
\hline $\begin{array}{l}\text { 6. Waste Disposal Facility } \\
\text { a. Good } \\
\text { b. Poor }\end{array}$ & $\begin{array}{c}41 \\
1\end{array}$ & $\begin{array}{c}97.7 \\
2.3\end{array}$ \\
\hline
\end{tabular}




\begin{tabular}{|c|c|c|}
\hline Variable & Frequency & $\begin{array}{l}\text { Percetg. } \\
\text { (\%) }\end{array}$ \\
\hline \begin{tabular}{|c|} 
7.The presence of Pet \\
a. Present \\
b. None
\end{tabular} & $\begin{array}{l}29 \\
13 \\
\end{array}$ & $\begin{array}{l}69 \\
31 \\
\end{array}$ \\
\hline $\begin{array}{c}\text { 8.Flood History } \\
\text { a. Present } \\
\text { b. None }\end{array}$ & $\begin{array}{l}12 \\
30\end{array}$ & $\begin{array}{l}28.6 \\
71.4\end{array}$ \\
\hline $\begin{array}{l}\text { 9.Tidal Flood History } \\
\text { a. Present } \\
\text { b. None }\end{array}$ & $\begin{array}{c}6 \\
36 \\
\end{array}$ & $\begin{array}{l}14.3 \\
85.7\end{array}$ \\
\hline \begin{tabular}{|r|} 
10.Vegetation \\
a. $\geq 3$ types \\
b. $<3$ types \\
\end{tabular} & $\begin{array}{l}25 \\
17\end{array}$ & $\begin{array}{l}59.5 \\
40.5\end{array}$ \\
\hline
\end{tabular}

As of the case in Demak District, the activity of men who will directly clean the environment after flood causes the possibility of exposure to the contaminant environment even larger.

Occupation of the respondents is also at risk to exposure to contaminants or animals infected with Leptospirosis. It can be seen from the result of this research that the characteristic of the occupation of respondents is labor farmer, and scavenger. Farmers are at risk to the rice fields contaminated with
Leptospirosis from rat droppings. Construction laborers are at risk to the dirty water contaminated by Leptospira when working, i.e. during stirring of cement. Scavengers are at risk of direct contact with the rat droppings while searching for rubbish in the trash, as rats often roam for food in the trash. Respondents' location to look for rubbish is in Semarang City. Semarang City is one of the endemic areas of Leptospirosis, so there is a high possibility of transmission occurred when looking for rubbish.

Demak District is an area with high rainfall that is 534-3.331 mm/year. More than half of cases occur in areas with high rainfall $\geq 220 \mathrm{~mm} /$ month $(64.7 \%)$.

The condition of Demak District which is mostly lowland so more than half of its area is used for irrigation rice field. The existence of large river or river irrigation becomes a strong factor of flood during rainy season. A flood occurs due to the overflow of river water. The habit of throwing rubbish in the river make the volume of river shrinks so water will be overflowed when the water debit start to increase. In addition, the result of this study also indicates that the respondents are living in housing with poor sewerage conditions and poor waste disposal facilities.
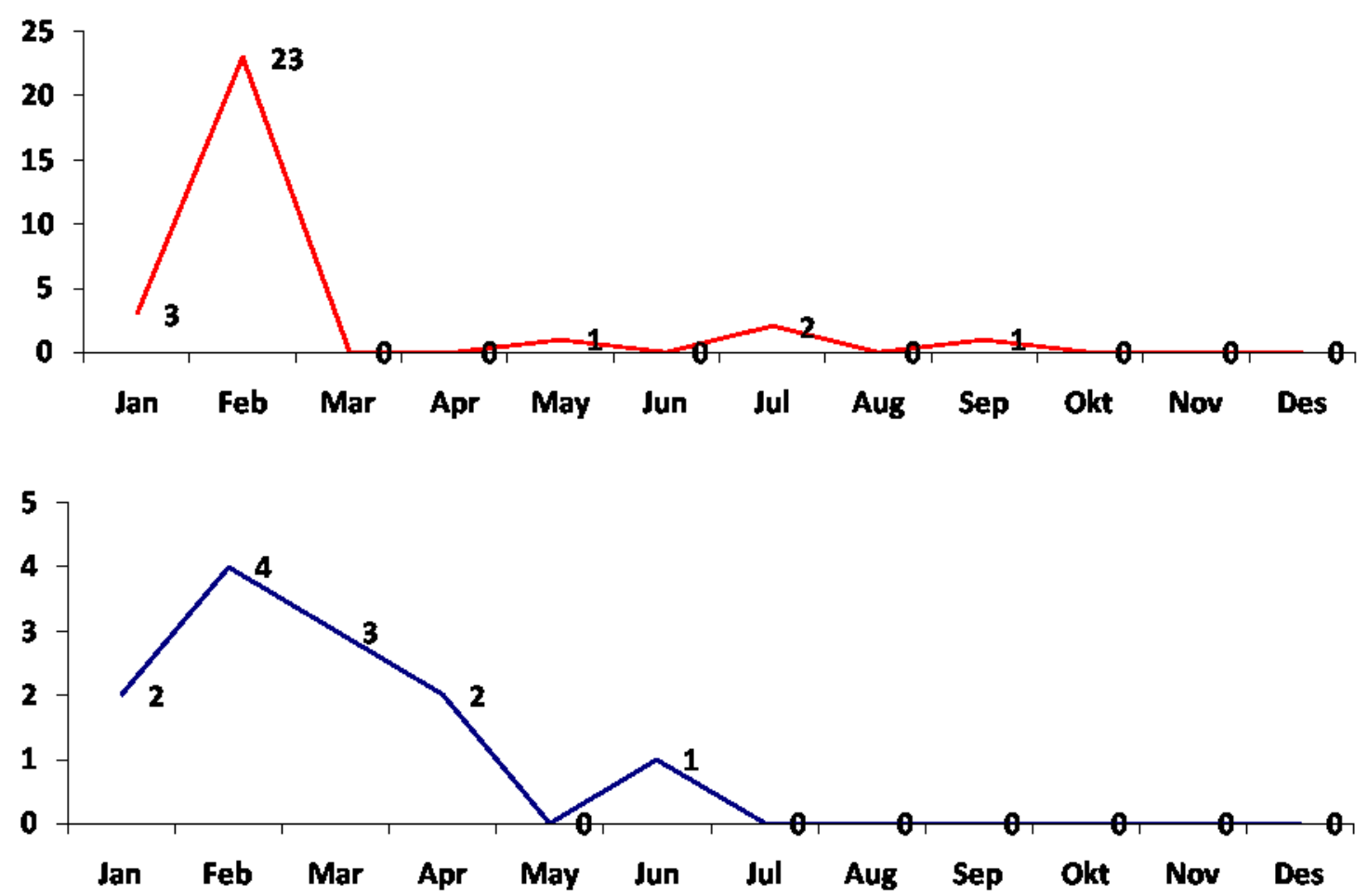

Fig.1 The Incidence of Leptospirosis Cases in Demak District Every Month in 2014-2015 
The incidence of Leptospirosis in Demak District in 2014-2015 is increasing during high rainfall (JanuaryFebruary) and still occurred during low rainfall. High rainfall is the cause of flood and resulted in the formation of puddles. The presence of puddles is supported by clay soil type in Demak District, so the water can stagnate longer [3], [29].

The altitude from sea level is an important variable for Leptospirosis cases spreading. Altitude condition is strongly associated with flood area and the location of permanent water logging [30], [31]. Mostly (98.9\%) Demak District area is lowland, except for half of Mranggen Sub-district and Karangawen Sub-district that has $\geq 47-100$ masl

Flooding and heavy rainfall have been associated with an increase of leptospirosis in specific in Albania. The study showed that Leptospirosis is spread in $47 \%$ teritory of the country with increase of incidence during the last two years. The most affected areas are the flooded areas of Shkoder, Fier and Lezha and also Berat and Tirana with single cases in other areas. The level of incidence has been increased from 0.1 cases $/ 10$ 000 in 2005 toward $1.8-2.5$ cases/ 10000 in 2010 and 2011. Climate change and floods may potentially result in an upsurge in the disease incidence over the last years [20].

Distribution of tidal flood history in Leptospirosis incidence in Demak District shows that flood history minimum once in 2 years occurred in 3 respondents houses $(7.1 \%)$. Tidal flood and flood are the same events that cause the widespread formation of water puddles that last for a long time. However, from the distribution of cases, there appears to be a difference between the distribution of cases in the area with flood history and the distribution of cases in the area with tidal flood history. In the distribution of cases in the area with flood history, there are a lot of cases occurred in Mangunjiwan Village area, that occurred 7 cases after the flood. As for the area with tidal flood history in Monosari Village, Sayung Subdistrict there are only 2 cases. This is possible because the $\mathrm{pH}$ of tidal flood water ranges from 8.3-8.5, whereas pathogenic Leptospira $s p$ survive in moist soil and fresh water for long periods of time, especially when the $\mathrm{pH}$ is slightly alkaline [13], [32]. Rats are the primary reservoir animals in Leptospirosis cases in Demak District. This can be seen from the results of this research showing the presence of rats either inside or outside the house of all respondents. Respondents claimed to have seen rats either inside or outside the house, to have seen rat's traces in the house or rat droppings inside the house.

The renal carrier state of rodents still remains a basic factor for the possible survival and spread of Leptospira $s p$. The primary source is the excretor rodent, from whose proximal renal tubules Leptospira $s p$ are excreted into the environment with urine. Although they are susceptible to environmental factors, in particular drying, they can survive for long periods in water and wet soil [18]. Respondents with rats in their house have 22.6 times greater risk of Leptospirosis compared to those who do not have rats in their house. And respondents who use vegetables ate by rodents have 4.6 times greater than who don't use vegetables ate by rodents [29].

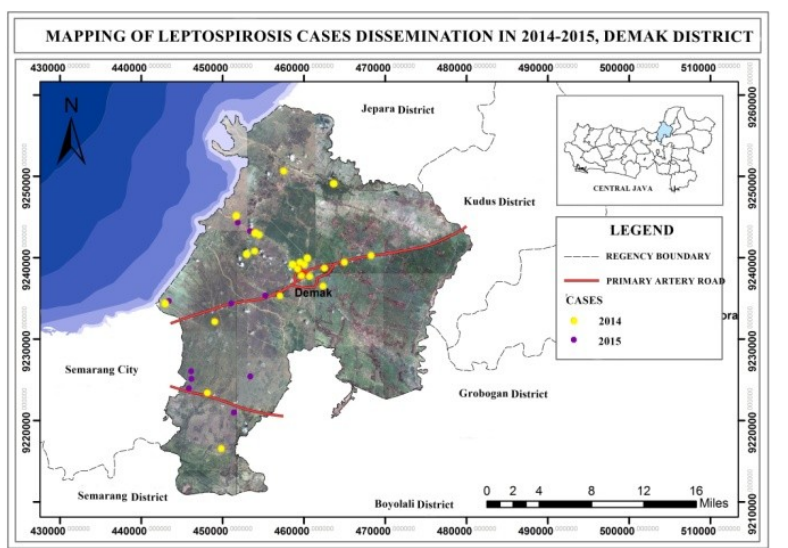

Fig.2. Dissemination of Leptospirosis Cases

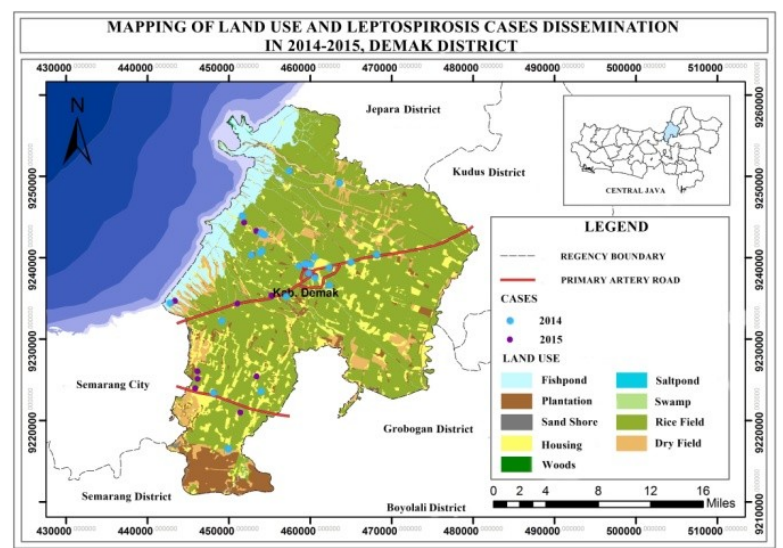

Fig.3. Land Use and Leptospirosis Cases Dissemination 


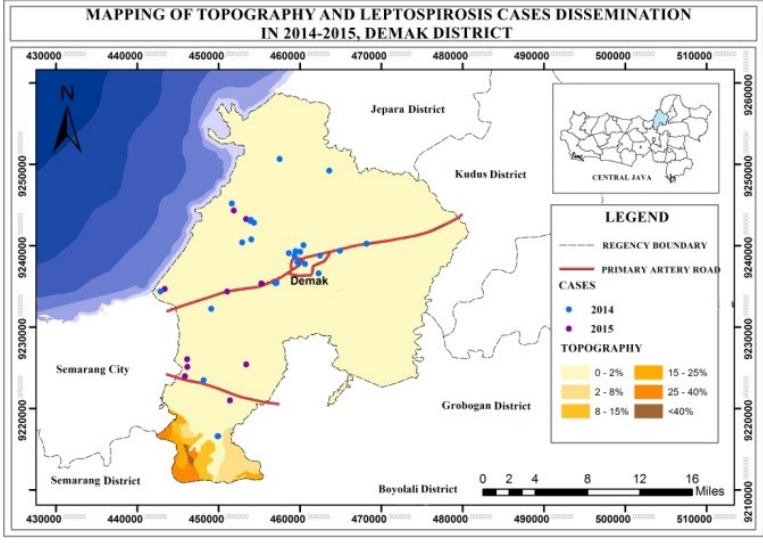

Fig.4. Topography and Leptospirosis Cases Dissemination

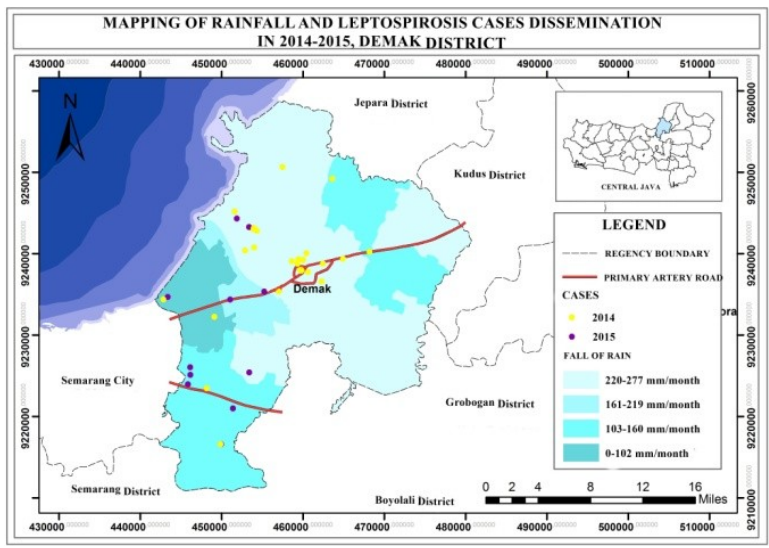

Fig.6. Rainfall and Leptospirosis Cases Dissemination

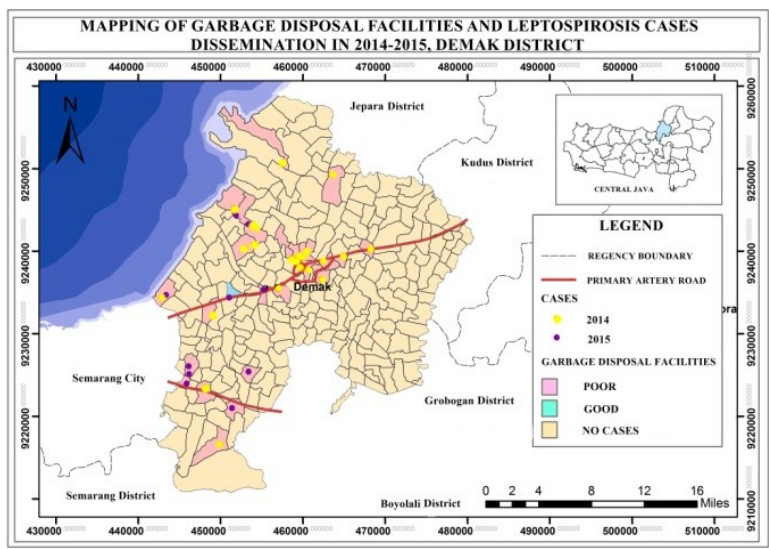

Fig.8. Garbage Disposal Facilities

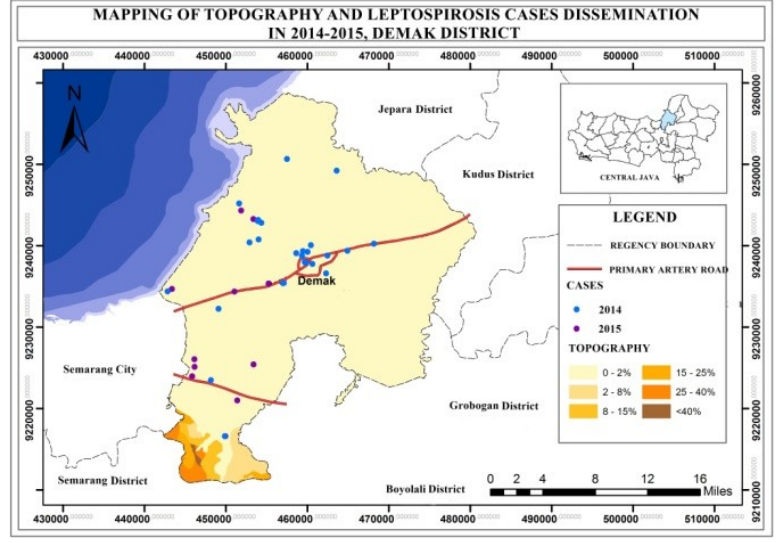

Fig.5. Type of Soil and Leptospirosis Cases Dissemination

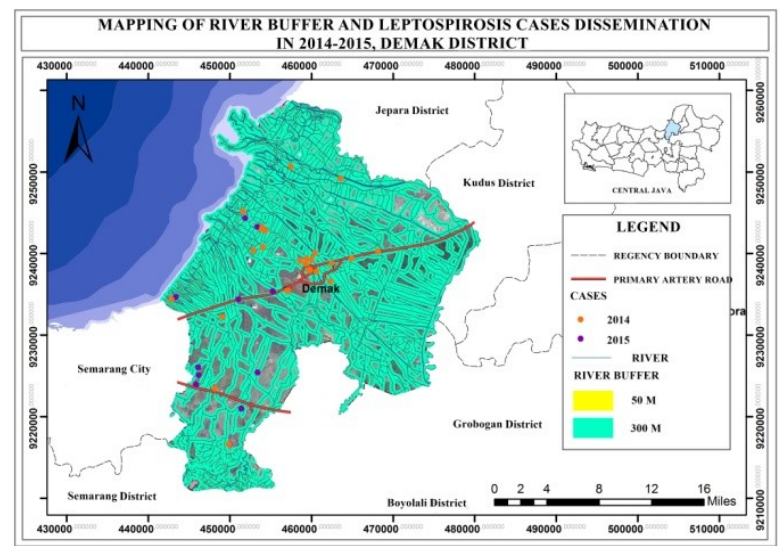

Gig.7. River Buffer and Leptospirosis Cases Dissemination

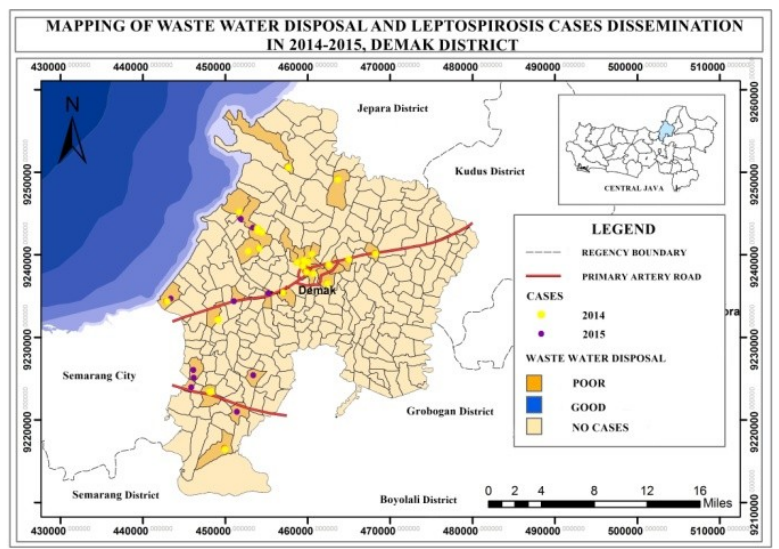

Fig.9. Waste Water Disposal Facilities 


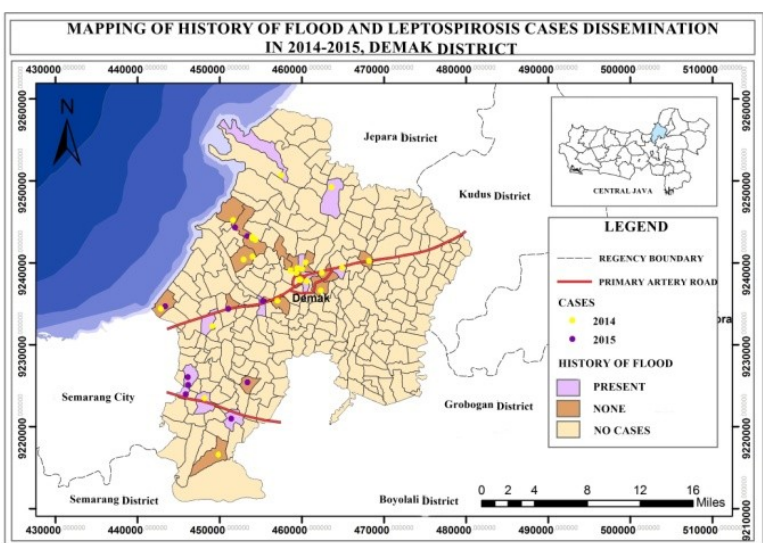

Fig.10. History of Flood

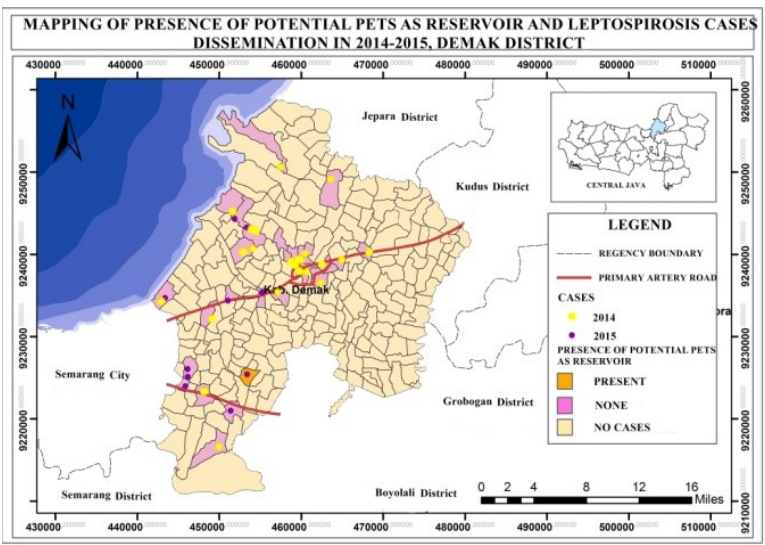

Fig.12. The presence of Potential Pests As Reservoir

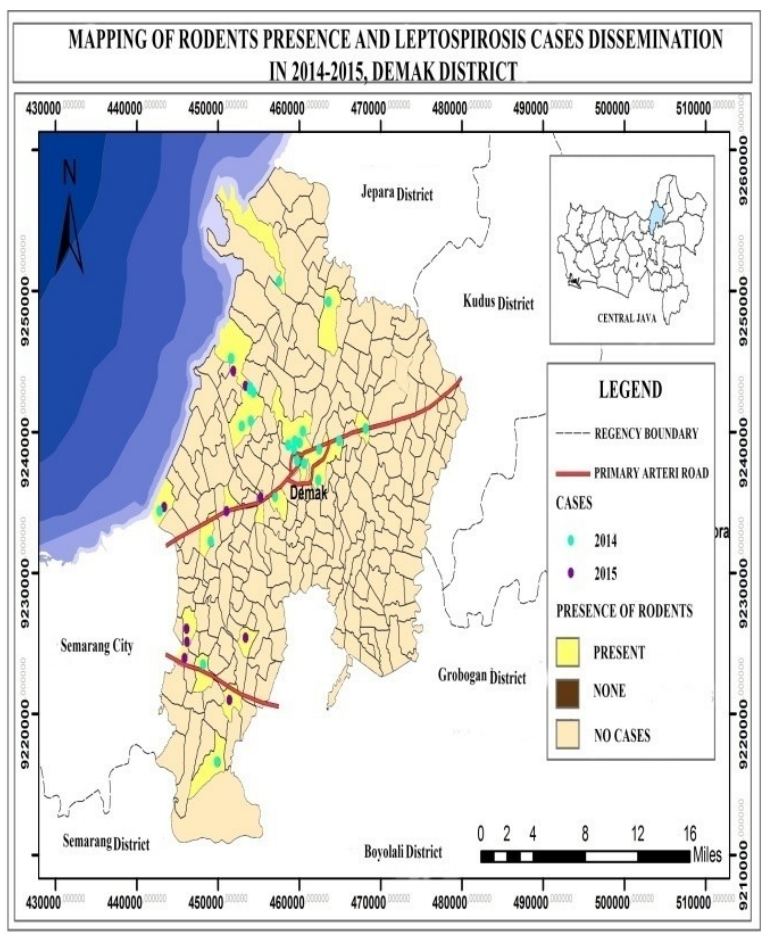

Fig.14. Presence of Rodents

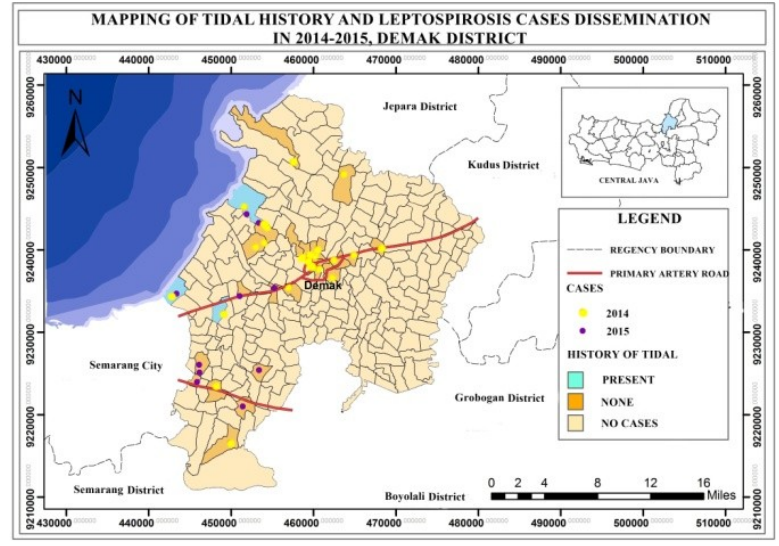

Fig.11. History of Tidal

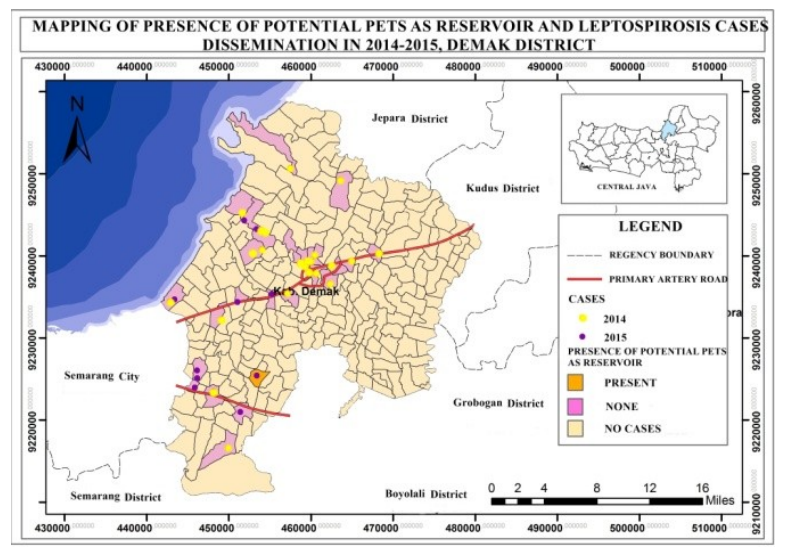

Fig.13. Vegetation Number

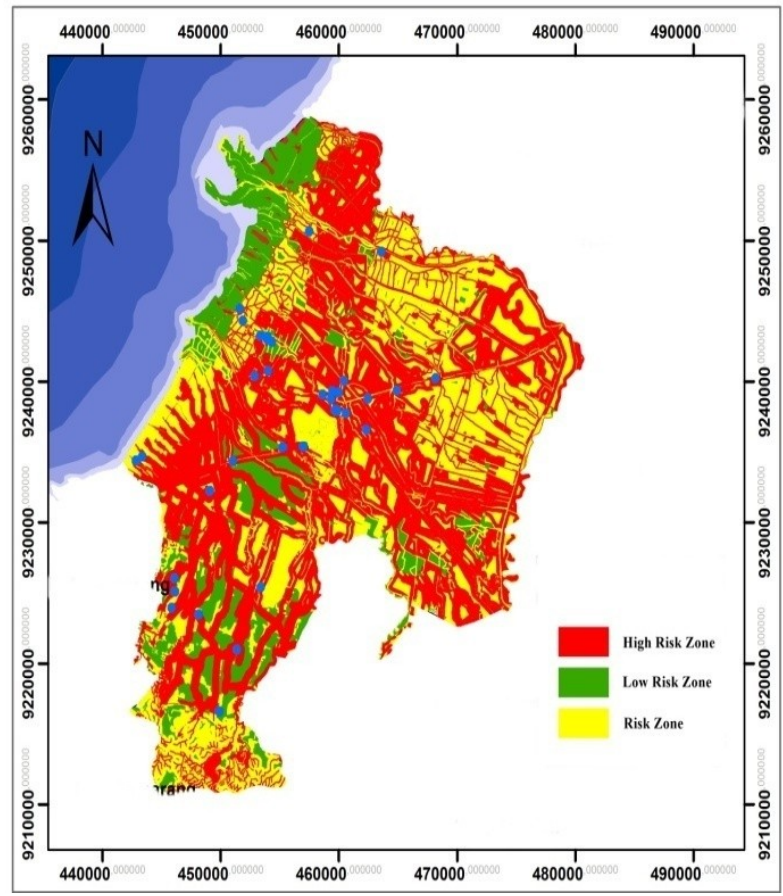

Fig.15. Mapping of Leptospirosis Vulnerable Zone in Demak District 
This can be seen from the results of this research showing the presence of rats either inside or outside the house of all respondents. Respondents claimed to have seen rats either inside or outside the house, to have seen rat's traces in the house or rat droppings inside the house.

The renal carrier state of rodents still remains a basic factor for the possible survival and spread of Leptospira $s p$. The primary source is the excretor rodent, from whose proximal renal tubules Leptospira $s p$ are excreted into the environment with urine. Although they are susceptible to environmental factors, in particular drying, they can survive for long periods in water and wet soil [18]. Respondents with rats in their house have 22.6 times greater risk of Leptospirosis compared to those who do not have rats in their house. And respondents who use vegetables ate by rodents have 4.6 times greater than who don't use vegetables ate by rodents [29].

Demak District is 89,743 ha which has 14 subdistricts and 243 villages. All of it is not leptospirosis risk zone. Handling determining and leptospirosis intervention is prioritized at a specific zone that is risk zone.

Making of leptospirosis vulnerable zone be based on leptospirosis vulnerable zone which is determined by environmental parameters that are land use, type of soil, river buffer, rainfall, topography, and vegetation.

Scoring and marking of all variables were based on variable influence great or environmental variable toward leptospirosis incident. Basic of scoring and marking are the result of first research and the result of the modification.

Table.2 Score, Mark, and Value at Environmental Parameters of Determining of Leptospirosis vulnerable zone in Demak District.

\begin{tabular}{|c|c|c|c|}
\hline $\begin{array}{c}\text { Environmental } \\
\text { Parameters }\end{array}$ & Score & Mark & Value \\
\hline \multirow{3}{*}{ 1. Land Use } & 3: Housing & \multirow[t]{3}{*}{6} & 18 \\
\hline & $\begin{array}{l}\text { 2: Rice field, } \\
\text { Plantation, woods, } \\
\text { Swamp }\end{array}$ & & 12 \\
\hline & $\begin{array}{l}\text { 1: Fishpond, } \\
\text { Tegalan, Dry field }\end{array}$ & & 6 \\
\hline \multirow{3}{*}{ 2. River Buffer } & $3:<50 \mathrm{~m}$ & \multirow[t]{3}{*}{5} & 15 \\
\hline & $2: 50-300 \mathrm{~m}$ & & 10 \\
\hline & 1. $>300 \mathrm{~m}$ & & 5 \\
\hline \multirow{2}{*}{ 3. Vegetation } & 2: $\geq 3$ Types & \multirow[t]{2}{*}{4} & 8 \\
\hline & 1: <3 Types & & 4 \\
\hline \multirow{2}{*}{ 4. Rainfall } & $2: \geq 220 \mathrm{~mm} /$ month & \multirow[t]{2}{*}{3} & 6 \\
\hline & $1:<220 \mathrm{~mm} / \mathrm{month}$ & & 3 \\
\hline \multirow{2}{*}{ 5. Type of soil } & 2: Clay, Loam, Silt & \multirow[t]{2}{*}{2} & 4 \\
\hline & 1: Sand & & 2 \\
\hline \multirow[t]{2}{*}{ 6. Topography } & $\begin{array}{l}2:<47 \text { masl and } 0- \\
2 \%\end{array}$ & \multirow[t]{2}{*}{1} & 2 \\
\hline & 1: $>47$ masl and $>2 \%$ & & 1 \\
\hline
\end{tabular}

Final scoring of all environmental parameters procured from a score of environmental parameter mark. Overlay executed after summing the value from each environmental parameters. Dissolve at the end of overlay executed with the aim to agglomerate the final result that has the same value at each environmental parameters so class-wide of leptospirosis vulnerable zone can be calculated.

After scoring, marking and value each environmental parameters, determination of classification leptospirosis vulnerable zone is determined. Spatial classification of leptospirosis vulnerable rate is using Sturgess method as reference. It divides the result of the number of maximal value decrement with the number of minimal value be based on the number of the class wanted. The determination result of scoring, marking, and value can be known that the number $\mathrm{f}$ maximum value is 53 and the number of minimal value is 21. Classification of leptospirosis vulnerable zone is divided 3 class which are high-risk zone, risk zone, and low-risk zone.

Classification $=($ The number of maximal value - The number of minimal value)/The number of class

Classification $=(53-21) / 3$

Classification $=10$

Table.3 Class of Leptospirosis Vulnerable Zone

\begin{tabular}{|l|l|l|}
\hline \multicolumn{1}{|c|}{ Class } & \multicolumn{1}{|c|}{ Interval } & \multicolumn{1}{c|}{ Zone } \\
\hline 1 & $43-53$ & High-Risk Zone \\
\hline 2 & $32-42$ & Risk Zone \\
\hline 3 & $21-31$ & Low-risk Zone \\
\hline
\end{tabular}

Leptospirosis high risk zone in Demak district is $37,801.8$ ha $(41.32 \%)$, risk zone is $43,570,23$ ha (48.55\%), and low risk zone is $9,090.96$ ha (10.13\%).

Leptospirosis risk zone in Demak is spread evenly in all of Demak area. It is caused by the area of Demak district which has low plain exploited as rice field. the leptospirosis high-risk zone spreads in all of Demak district area with forming a pattern on the river current because Demak district is the area which has many big rivers, a small river, and irrigation that can cause flood or puddle when the river water overflowing at the moment that raining. Leptospirosis high-risk zone is crowd and dirt housing which has near a location with river and rice field. 


\section{Conclusions}

1. More than half of the respondents are male with average age of 44 years old. The respondents' risk occupations are a farmer, construction laborers, and scavengers.

2. Leptospirosis cases in 2014 and 2015 have the same pattern of cases that are occurring during high rainfall (January and February) and during low rainfall or dry season (June and July) although the rain intensity is lower.

3. The condition of Demak District which has lowland area with clay soil type and high rainfall attributed to the occurrence of flood and puddles. The condition is exacerbated by poor sewerage and poor waste disposal facility.

4. Rats are the main reservoir of Leptospirosis cases in Demak District.

\section{Suggestions}

1. Cooperate with sectoral agencies regarding the prevention of flood by rejuvenating the functions of the river and digging the shallowing rivers so the water will flow smoothly during the rainy season.

2. Cooperate with relevant cross-sectoral agencies in rejuvenating the function of sewer and constructing a healthy sewer in residential areas.

3. Conducting efforts to eradicate rats, given the fact that rats are present in all areas of Leptospirosis cases.

\section{References}

1. World Health Organization, Human leptospirosis: guidance for diagnosis, surveillance and control. Geneva: World Health Organization, (2003).

2. A. R. Bharti et al., Lancet Infect. Dis., vol. 3, no. 12, pp. 757-771, Dec. (2003).

3. D. Benacer, P. Y. Woh, S. N. Mohd Zain, F. Amran, and K. L. Thong, Microbes Environ., vol. 28, no. 1, pp. 135-40,(2013).

4. D. Benacer et al., Asia. Pac. J. Public Health, vol. 28, no. 4, pp. 290-302, May (2016).

5. M. A. S. Johnson et al., Emerg. Infect. Dis., vol. 10, no. 6, pp. 1016-22, Jun. (2004).

6. P. R. Hunter, J. Appl. Microbiol., vol. 94 Suppl, p. 37S-46S, (2003).

7. A. M. Monahan, I. S. Miller, and J. E. Nally, J. Appl. Microbiol., vol. 107, no. 3, pp. 707716, Sep. (2009).

8. M. Sakundarno, D. Bertolatti, B. Maycock, J. Spickett, and S. Dhaliwal, Asia. Pac. J. Public Health, vol. 26, no. 1, pp. 15-32, Jan. (2014).
9. A. J. Mcbride, D. Athanazio, M. Reis, and A. I. Ko, Leptospirosis Curr. Opin. Infect. Dis., vol. 18, no. 5, pp. 376-386, (2005).

10. T. Fraga, E. Carvalho, L. Isaac, and A. Barbosa, in Molecular medical microbiology, 2nd Ed., Y.-W. Tang, M. Sussman, D. Liu, I. Poxton, and J. Schwartzman, Eds. Elsevier, pp. 1973-1990, (2014).

11. S. Craig et al., Ann Trop Med Parasitol, vol. 103, no. 7, pp. 647-51, (2009).

12. B. Adler and A. de la Peña Moctezuma, Vet. Microbiol., vol. 140, no. 3-4, pp. 287-96, Jan. (2010).

13. P. N. Levett, Clin. Microbiol. Rev., vol. 14, no. 2, pp. 296-326, Apr. (2001).

14. G. André-Fontaine, Vet. Microbiol., vol. 117, no. 1, pp. 19-24, Oct. (2006).

15. J. F. Prescott, B. McEwen, J. Taylor, J. P. Woods, A. Abrams-Ogg, and B. Wilcock, Can. Vet. J. =La Rev. Vet. Can., vol. 43, no. 12, pp. 955-61, Dec. (2002).

16. C. L. Lau, L. D. Smythe, S. B. Craig, and P. Weinstein, Trans. R. Soc. Trop. Med. Hyg., vol. 104, no. 10, pp. 631-638, Oct. (2010).

17. S. C. Sehgal, A. P. Sugunan, and P. Vijayachari, Natl. Med. J. India, vol. 15, no. 1, pp. 22-3, (1995).

18. P. Vijayachari, A. P. Sugunan, and A. N. Shriram, J. Biosci., vol. 33, no. 4, pp. 557-69, Nov. (2008).

19. R. B. Reis et al., PLoS Negl. Trop. Dis., vol. 2, no. 4, p. e228, (2008).

20. S. N. Fajriyah, A. Udiyono, and L. D. Saraswati, IOP Conference Series: Earth and Environmental Science, vol. 55, no. 1, (2017).

21. A. Butt, R. Shabbir, S. S. Ahmad, and N. Aziz, Egypt. J. Remote Sens. Sp. Sci., vol. 18, no. 2, pp. 251-259, Dec. (2015).

22. K. J. Dueker, Ntherlands: Elsevier Scientific Pub. Co, (1979).

23. V. Mesev, Comput. Environ. Urban Syst., vol. 21, no. 3-4, pp. 175-187, May (1997).

24. M. Haq, M. Akhtar, S. Muhammad, S. Paras, and J. Rahmatullah, Egypt. J. Remote Sens. Sp. Sci., vol. 15, no. 2, pp. 135-141, Dec. (2012).

25. M. K. Jat, P. K. Garg, and D. Khare, Int. J. Appl. Earth Obs. Geoinf., vol. 10, no. 1, pp. 26-43, Feb. (2008).

26. O. Berke, Prev. Vet. Med., vol. 71, no. 3-4, pp. 173-182, Oct. (2005).

27. R. K. Raghavan, K. M. Brenner, J. A. Harrington, J. J. Higgins, and K. R. Harkin, Geospat. Health, vol. 7, no. 2, pp. 169-82, May (2013).

28. W. Poeppl et al., Eurosurveillance, vol. 18, no. 25, p. 20509, Jun. (2013).

29. K. Swain, S. Pattanshetty, Ns. Nair, and R. Kamath, J. Glob. Infect. Dis., vol. 6, no. 1, p. 
3, Jan. (2014).

30. A. M. Dechet et al., PLoS One, vol. 7, no. 7, p. e39672, Jul. (2012).

31. C. Barcellos and P. C. Sabroza, Cad. saúde pública, vol. 17 Suppl, pp. 59-67, (2001).

32. E. Kupek, M. C. de Sousa Santos Faversani, and J. M. de Souza Philippi, Braz. J. Infect. Dis., vol. 4, no. 3, pp. 131-4, Jun. (2000) 